\title{
Responding to Students' Parents on National Examination Policy
}

\author{
Madehang \\ Institut Agama Islam Negeri Palopo \\ Palopo, South Sulawesi, Indonesia \\ made_hang@ymail.com
}

\author{
Nurlita Pertiwi \\ Faculty of engineering \\ Universitas Negeri Makassar \\ Makassar, Indonesia \\ nurlita.pertiwi@yahoo.com
}

\begin{abstract}
National Examination as public policy on education has been implemented by Indonesia government for several years. Debates about the national exam become a national issue that can obstruct the implementation of this policy. This study describes the responding of student's parents on national examination policy which has been held in South Sulawesi. This research was a descriptive qualitative research with the ethnomethodology approach and held on January - February 2017. The study interviewed 32 students' parents of five Senior High School. This research showed that there were two groups of students parents' responses about the implementation of National Examination using Computer Based Test (CBT). The first group with disagree response based on the problem focus on student problem and schools facilities. The second group with agree response based on the benefit of the new system to the student, school, and government.
\end{abstract}

\section{Keywords—student's parents, examination, policy}

\section{INTRODUCTION}

National Examination (NE) system is a national standard evaluation of primary and secondary education and equal quality education levels among regions. Implementation of the assessment system based on the Law of the Republic of Indonesia Number 20 The year 2003 on National Education System which states that to control the quality of education nationwide evaluation as a form of accountability of education providers to the parties concerned

Student assessment is an integral part of the education process that provides information on the quality of the learning process. Some countries use the same examination for both the purposes of certification and selection (such as Malaysia, India, Cambodia, Myanmar, Brunei Darussalam), while separate exams serve differing purposes in other countries (such as Japan, Australia, New Zealand). All ASEAN+6 countries (Japan, Australia, India, China, New Zealand, and the Republic of Korea) have examinations for either completion of upper secondary and/or entry to institutes of higher education[1].

National Examination (NE) has become a central issue for several years in Indonesia when the public policies declared by Indonesian Ministry of Education. This system is using two-way (Paper Based Test and Computer Based Test). Paper based on a national test that has been using for years, while Computer based test with a mechanism-based computer or distribution to the examination by the students use computers. The schools considered feasible to implement CBT system must meet the eligibility criteria of the aspects of infrastructure, teachers, and technicians who are competent, and the mental readiness of the students themselves.

As a matter of policy, different groups of people did not agree on the implementation of the national examination cased CBT. However, the government considered that this system could solve the problem in paper-based tests, such as the distribution of matter in the extensive area. This policy as one of the guides to the educational process. It relates to a wider or more general framework that the operation is based on philosophy, principle, vision and decision translated into various programs, projects, and activities. A policy entails the broad statement of future goals and actions and expresses the means of attaining them. [2].

Furthermore, the courage of the national exam passing standard is decided by agreement within the decision maker only. The graduation score standard is the same for each subject although the characteristics of subjects and the ability of learners are not the same. Besides, students have individual differences [3]-[6]. It is not a consideration for educational decision makers. Not necessarily in some degree of education, each subject has the same standards as the minimum standards of competence achievement. Some subjects demand the high achievement competence, while other subjects demand minimum competency achievement. This situation might be considered unfair to learners because they are required to exceed their maximum ability.

In Indonesia, the government has implemented a national examination based computers since 2016 for the high school level. Implementation national examination is currently used a semi-online system that is a matter sent from a central server online via the network (synchronisation) to a local server (school). Further examinations of students served by the local server (school) offline. The exam results saved on the local server at school uploaded to a central server online. Data in 2016 showed that 984 junior high school level, a Senior Haigh School in 1298 and Islamic Senior High School, in 2100 some vocational schools and 922447 participants.

Various community concerns, the government's policy have an impact on students' motivation will follow the national exam and other implementers such as teachers and 
school organisers. This paper aims at finding reasons why students' parents responding differed on the policy. This research is projected to contribute to the regional governments and the central government as the implementing national examination activities.

\section{RESEARCH METHOD}

This research was a descriptive qualitative research with ethnomethodology approach. Ethnomethodology is one of the perspectives in sociology which focuses on how people make sense of their life. This theory considers people as rational actors with a realistic way of thinking rather than official judgment to rationalise within society. The Ethnomethodology disputes that human being is reliant on these means to realise and demonstrate understanding. Harold Garfinkel developed the method following the theory by Alfred Schütz's on phenomenological reconstruction based on the Sociology theory of Max Weber's verstehen [7]-[9]. This research held on January - February 2017. The study interviewed 32 students' parents of five Senior High School in Palopo Regency. The Stages of data analysis begins by categorising and organising to form a pattern. Furthermore, researchers define the research themes. The final stage is a researcher triangulation by comparing the results of field observations.

\section{RESULT AND DISCUSSION}

The researcher found that there were two groups of respondents. The first group is the reaction of parents who do not agree on the public exam-based computer and the second is the response of parents who agree to a new pattern of national examinations. Moreover, organising stage on qualitative research produces that most parents agree with the implementation of the computer-based national exam. The researcher then performed a thematic grouping that responds to both types. The data showed that eight informants did not agree with the new system of state exams. The rationale of the response there is to potential students and potential school. A description of the reaction of parents who do not agree is presented in Table 1.

TABLE I. THE REASON OF DISAGREE RESPONSE

\begin{tabular}{ll}
\hline \multicolumn{1}{c}{ Focus } & \multicolumn{1}{c}{ Sub Focus } \\
\hline Student personality & $\begin{array}{l}\text { The fluently of students in computer use. } \\
\text { The psychological condition of students } \\
\text { during exams. }\end{array}$ \\
School characteristic & $\begin{array}{l}\text { Readiness of school about computer } \\
\text { facilities } \\
\text { Readiness teachers to carry on training for } \\
\text { students. }\end{array}$ \\
\hline
\end{tabular}

The other side there agreed in response to the implementation of the test. The informants respond based on the benefits of a computer-based test to students and schools and government. A description of the response of parents who agree is presented in Table 2 below.
TABLE II. THE REASON OF AGREE RESPONSE ORDERLY

\begin{tabular}{ll}
\hline \multicolumn{1}{c}{ Focus } & \multicolumn{1}{c}{ Sub Focus } \\
\hline Benefit for student & $\begin{array}{l}\text { Reduce the cheating risk of cheating } \\
\text { The test implementation is systematic } \\
\text { The presentation of question is more } \\
\text { interesting question }\end{array}$ \\
$\begin{array}{l}\text { Benefit for school and } \\
\text { government }\end{array}$ & $\begin{array}{l}\text { Test result announcement is earlier. } \\
\text { Printing and distribution of test are more } \\
\text { efficient. } \\
\text { Supervision of test is easier }\end{array}$ \\
\hline
\end{tabular}

Before concluding, the researcher carries on the triangulate the data with the results of observation. Observations show that some schools received support facility of the school committee. The school committee is an independent institution, consisting of parents of students, school community, and community leaders who care about education. This organisation directed parents to assist schools in implementing national evaluation with CBT system.

The baseline data at the school, the number of computers were only 25 units and only one server. The number of students who would take the national exam in 2017 was 289. The fact shows that the equipment for CBT was insufficient. The school needed more computers and servers. The school committee positioning is of course very strategic to support the school administration to support the CBT on student examining. Based on interviewed result indicated that student's parent supported the CBT policy. The students used their owning computers for assessment. Furthermore, the organisation provided charity or donate school for providing computer facilities.

The result of the research shows the response of student parents about national examination by using CBT based on the student personality and school facility. Agree to respond based on the community know about the benefit of the new system. Furthermore, the government as implementor of policy must provide intensive socialisation in the community about the implementation of the national examination by the computer based test.

Based on the previous research, the benefit of assessment using computer focused on the visualisation, audition and interaction. Visualization means that true colour image by proper resolution allowed the student to understand the object. Audition accommodate the student assessment for musical aptitude. The interaction means that the examination can serve full motion video or assessment of skill related to the human relation. [10], [11]. The other side this policy has an impact on new culture that supported by community and government.

This policy should consider the achievement standard to achieve in the classroom focusing on students' learning strategies as well as the motivation processes [12]. However, the national exam policy also should consider understanding the students are not in the same level of intelligent due to they have individual differences naturally [6]. Thus, students are expected to achieve the required standard and students have the motivation to learn. However, this policy requires significant contribution by the government that decide the policy and teachers that practice the teaching strategy and 
created motivation to provide students readiness to the best exam results.

\section{CONCLUSION}

There were two groups of responding students Parents about the implementation of National Examination by CBT. The first group with disagree response based on the problem focus on student problem and schools facilities. The second group with agree response based on on the benefit of the new system to the student, school, and government. This research showed the reaction of the parents of students on national examination using CBT based on the perspective of student personality and school facility. Parents of students showed the agree position to respond the community know that benefits to the new system. Also, the government as a policy maker is highly recommended to provide rigorous socialisation within the community about the realisation of the computer based national examination.

\section{REFERENCES}

[1] M.-H. Chou and P. Ravinet, "Higher education regionalism in Europe and Southeast Asia: Comparing policy ideas," Policy Soc., pp. 1-17, 2017.

[2] M. Howlett, Designing public policies: Principles and instruments. Routledge, 2010.

[3] J. Biggs, "Individual differences in study processes and the quality of learning outcomes," High. Educ., vol. 8, no. 4, pp. 381-394, 1979.

[4] F. Marton and R. Säljö, "On qualitative differences in learning: IOutcome and process," Br. J. Educ. Psychol., vol. 46, no. 1, pp. 4-11, 1976.

[5] R. S. Siegler, "Individual differences in strategy choices: Good students, not-so-good students, and perfectionists," Child Dev., pp. 833-851, 1988.

[6] R. M. Felder and R. Brent, "Understanding student differences," $J$. Eng. Educ., vol. 94, no. 1, pp. 57-72, 2005.

[7] H. Garfinkel, Studies in Ethnomethodology. Wiley, 1991.

[8] H. Garfinkel, Ethnomethodological studies of work. Routledge, 2005.

[9] H. Garfinkel, "Ethnomethodology's Program," Soc. Psychol. Q., vol. 59, no. 1, pp. 5-21, 1996.

[10] J. A. Bovaird, "Computer Based Testing," in Encyclopedia of CrossCultural School Psychology, Springer, 2010, pp. 256-257.

[11] D. L. Milne and R. Reiser, "Evidence-Based Supervisory Practices In CBT," Teach. Superb. Cogn. Behav. Ther., p. 207, 2015.

[12] C. Ames and J. Archer, "Achievement goals in the classroom: Students' learning strategies and motivation processes.," J. Educ. Psychol., vol. 80, no. 3, p. 260, 1988. 